\title{
Effect of Seismic Activity on the Gravitational Processes Trough the Example of the Butrointsi Rockfall, SW Bulgaria
}

\author{
Radostina RizovaA*, Georgi Nachev ${ }^{\mathrm{A}}$ \\ Received: February 26, 2015 | Revised: Novemeber 4, 2015 | Accepted: December 1, 2015
}

\begin{abstract}
This study investigates the relationship between rockfall and seismic activity. The article examines the development of the Butrointsi rockfall before the earthquake with a magnitude of Mw 5.6 on the Richter scale and the development which occurred as a result of the seismic activity. Comparing the rock blocks' size, their volume and the deposit's dynamics before and after the earthquake, the authors emphasize the role of the seismic factor for the activation of the rockfall process. Through the application of various methods (morphographics, morphometrics, sedimentologicals etc.) the authors make a complete profile of the deposits and calculate the amount of collapsed rocks caused by the earthquake.
\end{abstract}

The aim of this study is to emphasize the role of the seismic factor for the dynamics of the Butrointsi rockfall.

The authors analyze a combination of terrain data and laboratory results in order to gain insights into the initiation, dynamics and talus deposition of a complex rockfall.

Key words: gravity processes, butrointsi rockfall, morphodynamics, earthquake, seismic activity.

\section{Introduction}

The reason behind this article is the earthquake, which happened on May $22^{\text {nd }}$ 2012, with epicenter near Pernik $(5 \mathrm{~km}$ northwest of the city center, between the villages Meshtitsa and Vitanovtsi). The first and strongest quake was at 03:0o local time with a magnitude of Mw 5.6 (EMSC) and a hypocenter depth of $10 \mathrm{~km}$. ( $42^{\circ} 38^{\prime} 43^{\prime \prime}$ north, $22^{\circ} 59^{\prime} 56^{\prime \prime}$ east). The earthquake caused damage to many buildings in Pernik. The Butrointsi rockfall is situated about $29 \mathrm{~km}$ southeast of the earthquake epicenter. The main purpose of the study is to underline the role of the seismic factor for the development of the rockfall process and the landform. The Butrointsi rockfall has been monitored for a period of 4 years as one of the key areas in the dissertation paper of Rizova (2011). The gauging has been carried out for a sufficient period and provides reliable information about the morphodynamics in the area before the earthquake.

Object of study in this article is a rockfall, located in the left (moving to north-east) scarp on the road between the villages Filipovtsi and Butrointsi, in the northwestern part of Zavalska mountain.

Subject of study are the forms and deposits, formed as a result of the progress of the gravitational processes, in combination with the weathering of the rocks.

This study attempts to calculate the deformations caused by the earthquake in terms of amount of collapsed mass and the sizes of the newly collapsed rock blocks. The obtained data is compared to the dynamics of the rockfall before the earthquake in order to highlight the role of the seismic factor.

\footnotetext{
1 Department of Geology and Geoinformatics, Faculty of Geoexploration, University of Mining and Geology, 1700 Sofia, Student's Town, Bulgaria

* Corresponding author: Radostina Rizova, e-mail: r.rizova@mgu.bg
} 


\section{Methods and data}

The results, obtained in this paper, came from combination of field and laboratory methods. During the field study of the key unit, samples were taken for granulometric analysis, morphoscopic analysis and petrographic analysis of thin sections. At the same time marked stakes were placed (Klyukin, Tolstykh, 1984) in order to monitor the intensity of the current morphodynamic processes in the region.

The morphoscopic and granulometric analysis were performed by the method of Baltakov (1988) and Serebryanyi (1980). The results of the granulometric analysis with aggregate fractions are presented in tables and histograms. Petrographic description is performed by microscopic examination of two thin sections. On the topographic map in scale 1:500o various morphometric studies were made with a view to create a slope map. The steep slopes are an important condition for the development of rockfalls.

\section{Geologic and geomorphologic setting}

The Butrointsi village is located at the northwest flank of the Zavalska mountain (Kitka peak, $1160 \mathrm{~m}$ a.s.1.), Western Bulgaria (Figure 1). From a geomorphic point of view this mountain is part of the Zavalsko-Planska mountain range in the West Srednogorie (Kanev, 1989). It spreads in the northwest direction from the Breznishki Greben to the Vrabchanska saddle. The crest of the Zavalska mountain is southwest oriented. It is steep and narrow. The mountain is built of Upper Cretaceous volcanic and sedimentary rocks. The relief is structure-controlled.

In geomorphological sense, parts of Zavalska mountain have been studied by Konstantinov (1985), Velchev (1998), Konstantinov and Kanev (1986). In their researches they affect some problems related to the tectonic, parts of the foot of the mountain or the catchment area of some rivers. Publications for this region have also Boyadzhiev (1979), Vaptsarov (1985), Kanev (1989), Kostadinov (1974) and others. A complete geomorphological study of Zavalska Mountain hasn't done yet.

The relationship between rockfalls and seismic activity is mentioned in the studies of many authors, such as Marzorati et al. (2002), Luuk, Dorren (2003), Rosser et al. (2007), Mavrouliı et al. (2009), Lacroix, Helmstetter (2011), Zimmer et al. (2012), Lari, et al. (2014), etc. Trough various investigations and calculations they prove the role of seismic factor for the development of rockfall processes and forms.

For the purposes of this study, a Digital Elevation Model (DEM) was created (Figure 2). The DEM contains elevation every $40 \mathrm{~m}$. Altitude values in the re-

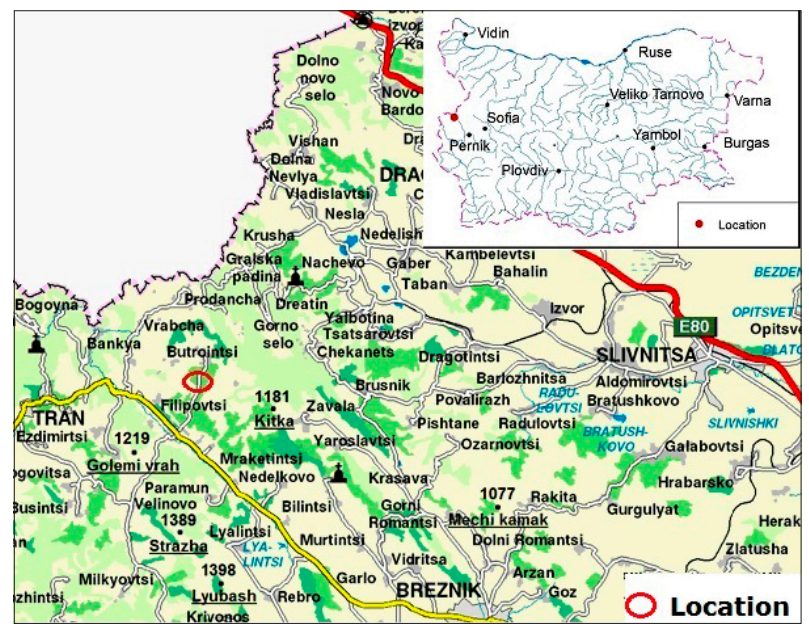

Figure 1. Geographical location of Butrointsi rockfall in Zavalska mountain (Western Bulgaria)

search area vary from $790 \mathrm{~m}$ in the midstream of the Butroinska River to $1085 \mathrm{~m}$ - northeast of the village Butrointsi. Exceedances of the relief reaches up to 295 $\mathrm{m}$. The altitude decreases from the northeast to the southwest, and from the watershed to the carved valley of Butroinska River.

The rock involved in the rockfall process has cataclastic structure, with partial recrystallization of some of the main minerals. It consists of calcite, which comprises about 90\% of the thin section. Quartz takes second place with about $6 \%$. Plagioclase, clay minerals and hydroxides each have a share of about $2 \%$ (Figure 3 ).

Calcite is represented by bio detritus grains (1$3 \mathrm{~mm}$ ) in a varying degree of mechanical disintegra-

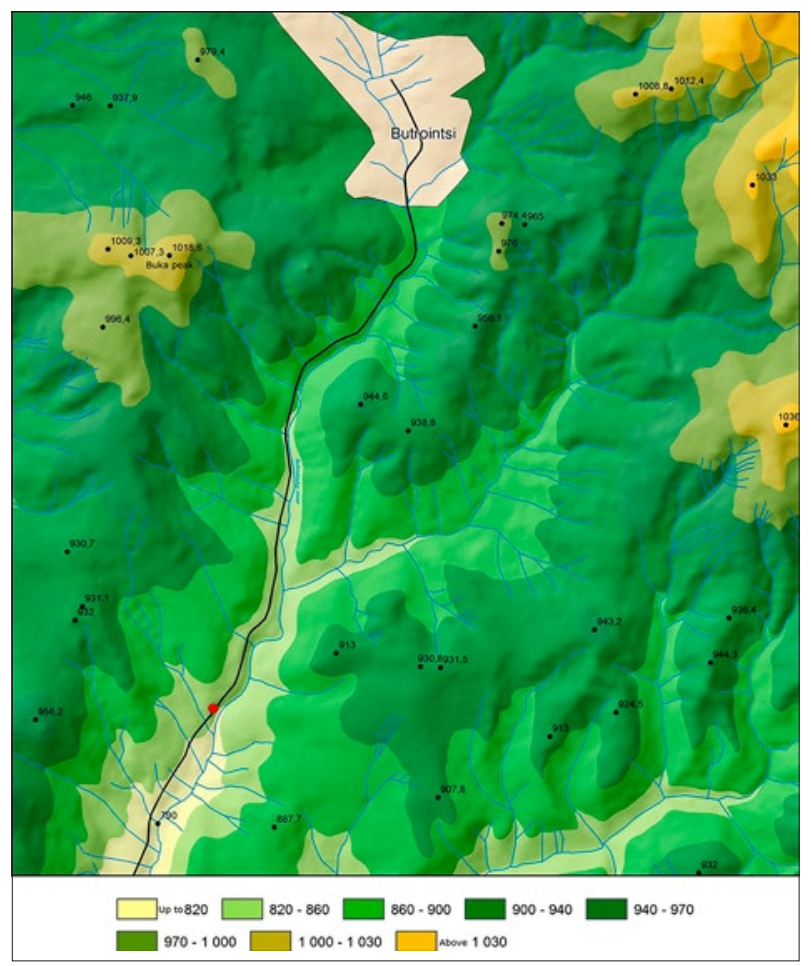

Figure 2. Digital Elevation Model and hypsometry 


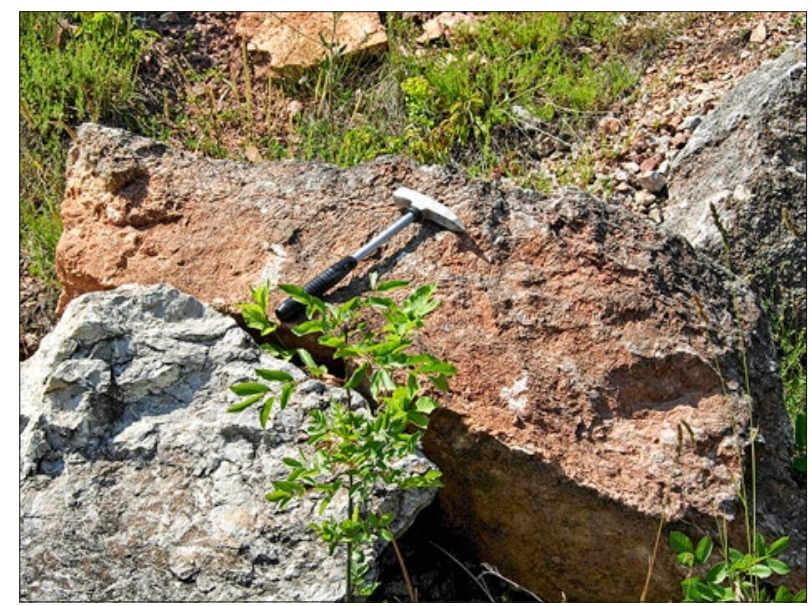

Figure 3. Limestone blocks, forming the Butrointsi rockfall

tion and recrystallization. The primary grains are relatively large single crystals with partially preserved forms of crinoid members. The crystallographic twins are bent at the periphery of the grains. Secondary clear grains have developed in cracks of the old grains as a result of the recrystallization.

Quartz is represented by angular grains with undulose extinction. The angular grains are cracked and calcite material penetrated in the cracks. Some of the grains are boudinaged and between the boudins carbonate is injected. Dislocation of the quartz fragments after the deformation can be observed. Being a fragile and solid material the quartz shows a clear deformation pattern, when distributed among the more plastic carbonate material and in some places it is transformed into a mosaic of clear smaller grains - mortar structure. Some of the quartz grains have partially preserved oval shape, which indicates that before the deformation they were a terrigenous component in a sandstone. Feldspar is also deformed and partially replaced by secondary grains, the product of a dynamic recrystallization. These grains are distinctly visible on the periphery of the larger feldspar grains.

It can be concluded that this is a carbonate terrigenous rock (calcarenite), which was deformed in a tectonic zone, and under the effect of mechanical shear, reduced to tectonic breccia. The traces of dynamic recrystallization in the grains resemble that of a lowgrade regional metamorphism and show the intensity of the shearing process.

The nature of the processing indicates that the rockfall is located in the peripheral part of a large fault or a shear zone.

The crushed material was infiltrated by meteor water so the carbonate is partially dissolved. Residual ferric hydroxide and clay products have formed and are deposited in the gaps between breccia fragments. As there is no evidence of multiple and complex in na- ture karsting, it is highly likely that the tectonic zone is relatively young and belongs to the system of neotectonic faults in the area.

\section{Slope analysis}

Slope gradients are calculated by the method of Burrought and McDonell (1998). The intput data came from topographic maps in scale 1:5000, which contain the most accurate and detailed terrain data of Bulgaria (excluding more modern aerial photos). Based on this data contours and elevations with altitude are digitized, which helps generate a relief model, based on "least squared distance" procedure with a pixel size $5 \times 5 \mathrm{~m}$. From the so created model of the relief, a map of the slopes is generated using Arc GIS. For each pixel the Slope tool calculates the maximum rate of change in height values of the adjacent pixels. On the basis of all the calculated values, a map of slopes is generated (Figure 4). The map created using this method enables us to change the degree classes for visualization purposes, thus facilitating analysis and future inspections.

The calculation of the average slope in the area outlines the following features in their spatial distribution. The minimum registered slope values are $7^{\circ}$, while the maximum are $44^{\circ}$ (Table 1 ).

Relatively flat surfaces with slopes up to $10^{\circ}$ are observed on the periphery of rivers in watershed areas. Flat terrains occupy the largest part of the research area $-24 \%$. They are characterized with creep of the weathered cover. Hills with slopes of $10^{\circ}$ to $15^{\circ}$ and $15^{\circ}$ to $20^{\circ}$ are of almost equal area. The steep slopes are carved by short rivers. They are ususally situated on the periphery of the watershed strips. Accelerated creep and sheet erosion is dominant in these areas. Areas with a slope of $20^{\circ}$ to $25^{\circ}$ and of $25^{\circ}$ to $30^{\circ}$ are found in $17 \%$ and $10 \%$ of the studied area. These steep sections are attached to midstreams of rivers of I and II order. Intense denudation occurs on the precipitous valley slopes.

Slopes with maximum steepness - from $30^{\circ}$ to $35^{\circ}$ and above $35^{\circ}$ occupy a limited area - only $3 \%$. They

Table 1. Slopes acreage and \% of the area

\begin{tabular}{|l|c|c|}
\hline Slope in degrees & Territory (ha) & $\%$ of the total area \\
\hline up to 10 & 19.77 & 25.30 \\
\hline $10-15$ & 16.36 & 20.94 \\
\hline $15-20$ & 13.78 & 17.64 \\
\hline $20-25$ & 11.99 & 15.35 \\
\hline $25-30$ & 8.73 & 11.18 \\
\hline $30-35$ & 4.53 & 5.81 \\
\hline above 35 & 2.95 & 3.78 \\
\hline total & 78.14 & 100.00 \\
\hline
\end{tabular}




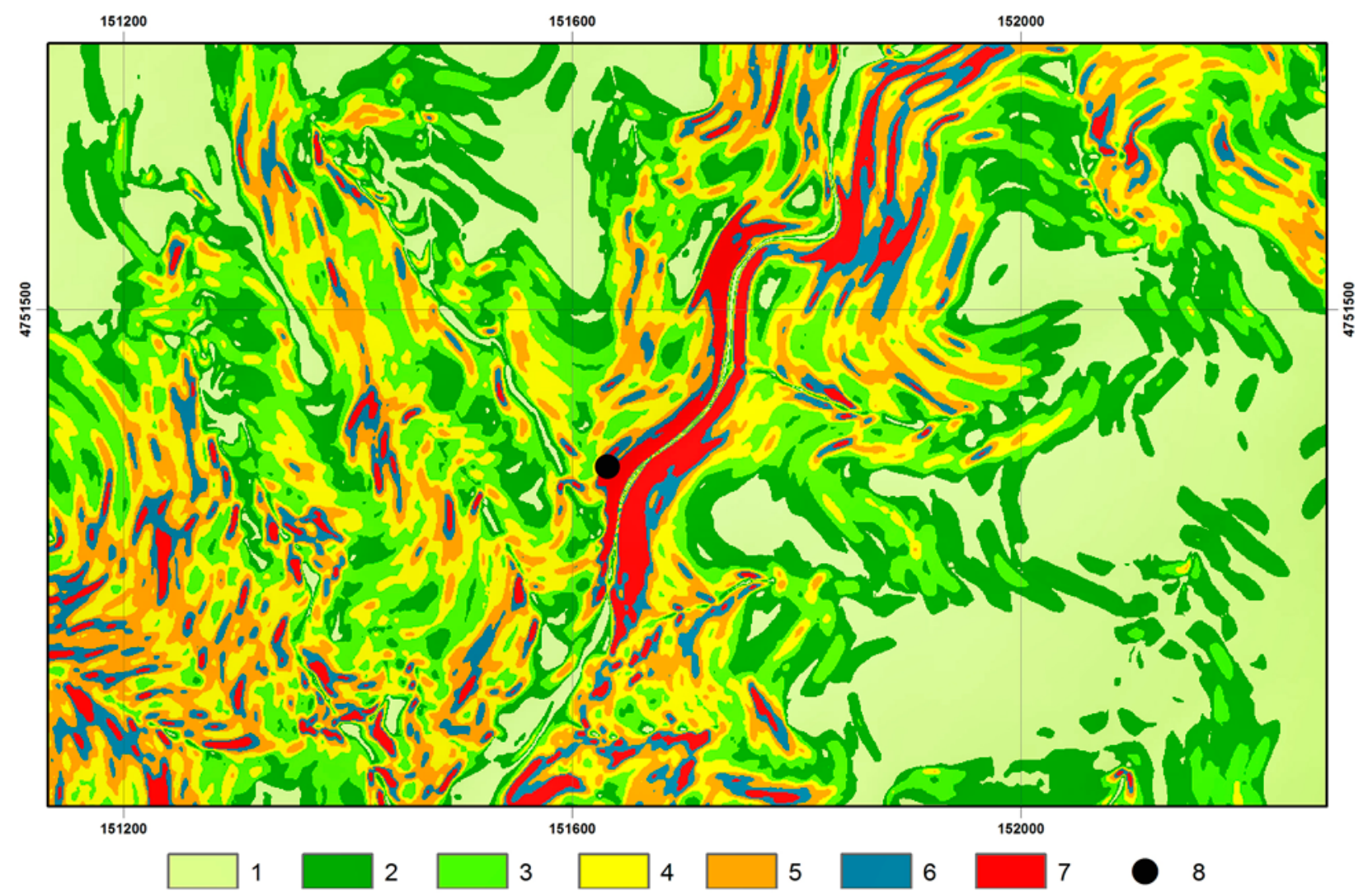

Figure 4. Slope map: 1) - to $\left.\left.\left.\left.\left.\left.10^{\circ}, 2\right)-10-15^{\circ}, 3\right)-15-20^{\circ}, 4\right)-20-25^{\circ}, 5\right)-25-30^{\circ}, 6\right)-30-35^{\circ}, 7\right)$ - over $35^{\circ}$, 8) - studied site

are attached to the valley slopes of the deeply-carved river valleys of higher order, which are tectonically imposed and trace faults. Gravitational processes are a common characteristic of these slopes. Usually rockfalls develop on slopes steeper than $27^{\circ}$ (Konstantinov, 1986). The map of slopes (Figure 3) shows that the study site is located in an area with maximum gradient values - greater than $35^{\circ}$.

As a result of the analysis of the basic data of the slope gradients it was established that splash erosion, along with active denudation processes and sheet erosion prevail. A relatively small part of the total area is subject to intense gravitational processes.

\section{The rockfall at the beginning of observation}

The rockfall (Figure 5) is situated 2,2 km northeast of Filipovtsi and $1,8 \mathrm{~km}$ southwest of Butrointsi. As the rockfall is closer to Butrointsi, the authors offer, for more convenience, to be named after this village. It is located above the confluence of some streams of first order, which take their source from the Buka peak (1018, $6 \mathrm{~m}$ a.s.l.). They flow into the Butroinska river, which is a right tributary to the Yablanitsa river. The exposition is southeast. The altitude is $855 \mathrm{~m}$. The exact location is $42^{\circ} 50^{\prime} 12^{\prime \prime}$ north, $22^{\circ} 44^{\prime} 24^{\prime \prime}$ east.

The scarp of the rockfall is about $6 \mathrm{~m}$ high. At its base there is a debris funnel with a thickness of about $3 \mathrm{~m}$ (Figure 5). The rocks are intensely fractured with horizontal and subvertical cracks. The vertical crevices are secondary and less common. The scarp consists of jointed limestone and is approximately $4 \mathrm{~m}$ high. The accumulative part (the trail) is over $2 \mathrm{~m}$ thick and about $8 \mathrm{~m}$ long. The latter consists of two segments. One, which is relatively older, is formed by sand and gravel. On top of the fine grained underlayer larger rock blocks collapsed. Their maximum sizes vary as follows: $88 / 78 / 60 ; 70 / 50 / 30 ; 90 / 60 / 75 /$; 102/80/70; 80/60/40; 75/55/50; 142/110/100; 12/5/4 (in $\mathrm{cm})$.

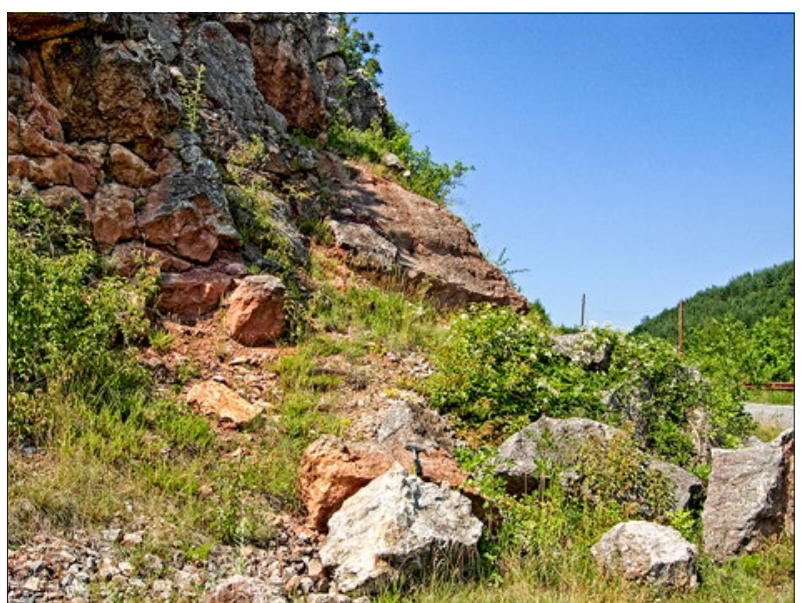

Figure 5. The Butrointsi rockfall at the beginning of the observation (2006) 
Table 2. Results of granulometric analysis in numbers

\begin{tabular}{|c|c|c|c|c|c|}
\hline sample & rubble \% & gravel \% & sand \% & silt \% & Color in Munsell chart \\
\hline R2 & 12.35 & 33.35 & 26.3 & 28.1 & $5 Y R$ 6/4 light reddish brown \\
\hline
\end{tabular}

\section{Granulometric analysis}

The sample was picked up from the sandy underlayer of the rockfall. The fractions of the granulometric analysis are shown on Table 2 and on the histogram (Figure 6).

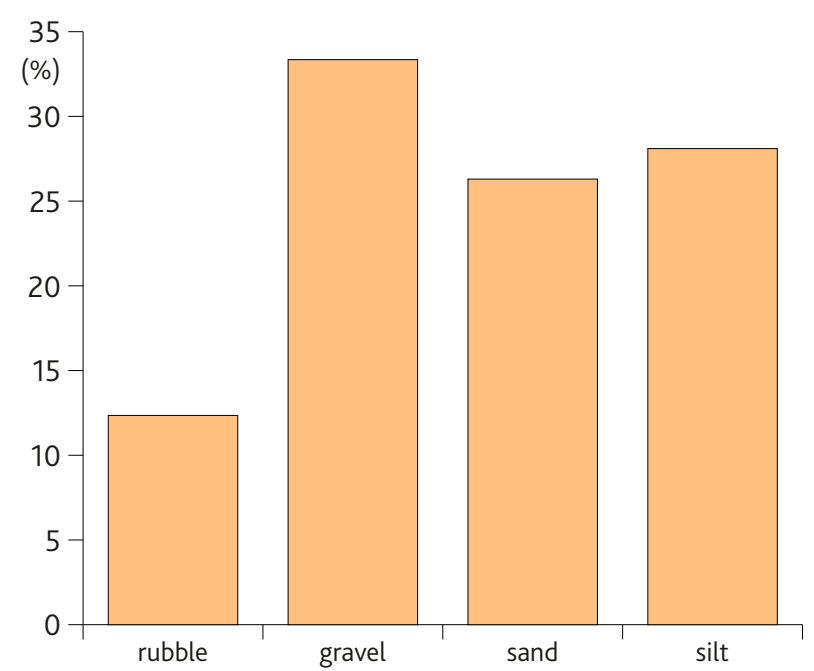

Figure 6. Results of granulometric analysis in histogram

The following conclusions can be made based on the results. The filler is clay-sandy. The deposits contain mixed fractions. Sand, gravel and clay have an almost equal share. The large pieces (blocks and gravel) make up to $46 \%$ of the sample and the small ones (clay and sand) up to $54 \%$. The gravel's share in is the smallest. Although this is not typical of a rockfall process, it can be explained by the fact that the sample has been taken from the lower part of the rockfall, where more sand is present. After they are detached from the massif, the rock fragments are subject to continuous exogenous influence, which results in further disintegration.

\section{Morphoscopic analysis}

The morphoscopic analysis has been carried out by examining 30 rock pieces (Figure 7). All of the pieces have similar petrographic composition - limestone, although some pieces have an outer calcite crust and orange coloration. The age of the limestone is Upper Cretaceous (Zagorchev and al., 1991). The results of the morphoscopic analysis are presented in Table 3.

The conclusions, obtained through the morphoscopic analysis are as follows: The average dimensions of the rock fragments on axes " $a$ ", "b" and "c" are respectively: 40, 30 and $22 \mathrm{~mm}$. The maximum dimensions reach up to 90,63 and $41 \mathrm{~mm}$. These results from jointing in the upper part of the massif, where between 10 and 15 joints per linear meter are observed. The roundness of all fragments is o (according to the scale of Serebryanyi, 1980). This is characteristic of the rockfall process. It indicates the fact that gravity is the main driving force and the transport is short. The ma-

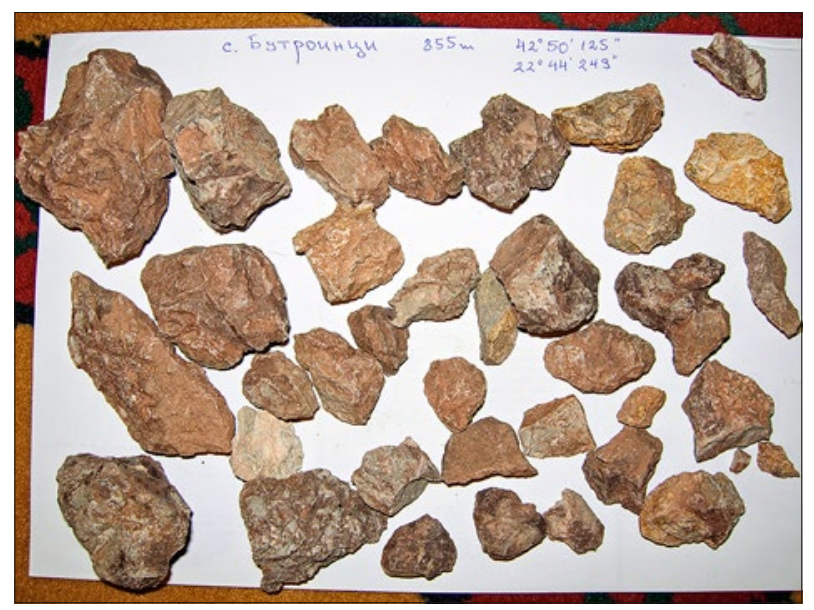

Figure 7. Rock samples for morphoscopic analysis

jority of the fragments are spherical (47\%) and $27 \%$ are cylindrical. The form indicates that the mechanism of transport is saltation.

\section{Observation on marked stake}

In early 2006, during the first visit, we placed a small wooden stake in the bottom (accumulative) part, with the hope of capturing rockfall at close and tracking the dynamics of the deposits. The marked stake is regularly observed for the entire 4-year period (Figure 8). The following conclusions can be drawn from the obtained data: The maximum denudation is 23.8 $\mathrm{cm}$, where the stake is completely bare, upturned and moved at a 1-metre distance down the slope; the minimum denudation is $2 \mathrm{~cm}$. The average rate of denudation is $5.95 \mathrm{~cm}$ per year. Early spring (April, May) is the period, when the most active slope denudation occurs. The highest rates of denudation and the largest collapsed rock fragments have been registered during this period. Late autumn (October, November) proves as the second period of high denudation activity. The denudation activity is at its lowest in the summer and in the winter.

Research has shown that triggering mechanisms such as intense rainfall, snowmelt or freeze-thaw conditions are the most common reason for the mass movement. During the most active season (the 
Table 3. Results of the morphoscopic analysis (method of Serebryanyi, 1980)

\begin{tabular}{|c|c|c|c|c|c|c|c|}
\hline \multirow{2}{*}{ № } & \multicolumn{3}{|c|}{ Dimensions mm } & \multirow{2}{*}{ Petrographic composition } & \multicolumn{3}{|c|}{ Shape } \\
\hline & a & $\mathrm{b}$ & c & & $c / b$ & $\mathrm{~b} / \mathrm{a}$ & name \\
\hline 1 & 62 & 48 & 28 & limestone & 0,58 & 0,77 & disc shaped \\
\hline 2 & 43 & 34 & 21 & limestone & 0,62 & 0,79 & disc shaped \\
\hline 3 & 44 & 29 & 18 & limestone, orange colored & 0,62 & 0,65 & flat-elongated \\
\hline 4 & 90 & 36 & 25 & limestone & 0,69 & 0,4 & cylindrical \\
\hline 5 & 56 & 46 & 31 & limestone & 0,67 & 0,82 & spherical \\
\hline 6 & 47 & 41 & 34 & limestone & 0,83 & 0,87 & spherical \\
\hline 7 & 78 & 63 & 39 & limestone & 0,62 & 0,80 & disc shaped \\
\hline 8 & 53 & 47 & 41 & limestone & 0,87 & 0,88 & spherical \\
\hline 9 & 45 & 37 & 34 & limestone & 0,92 & 0,82 & spherical \\
\hline 10 & 35 & 34 & 18 & limestone & 0,52 & 0,97 & disc shaped \\
\hline 11 & 55 & 44 & 37 & limestone, foreign calcite crust, orange colored & 0,84 & 0,80 & spherical \\
\hline 12 & 45 & 26 & 21 & limestone & 0,80 & 0,57 & cylindrical \\
\hline 13 & 41 & 34 & 24 & limestone, foreign calcite crust & 0,70 & 0,82 & spherical \\
\hline 14 & 41 & 27 & 18 & limestone & 0,66 & 0,65 & spherical \\
\hline 15 & 41 & 24 & 14 & limestone & 0,58 & 0,58 & flat-elongated \\
\hline 16 & 43 & 38 & 37 & limestone & 0,97 & 0,88 & spherical \\
\hline 17 & 37 & 34 & 20 & limestone & 0,58 & 0,91 & disc shaped \\
\hline 18 & 35 & 19 & 16 & limestone, foreign calcite crust & 0,84 & 0,54 & cylindrical \\
\hline 19 & 38 & 30 & 26 & limestone, foreign calcite crust, orange colored & 0,86 & 0,78 & spherical \\
\hline 20 & 46 & 41 & 25 & limestone & 0,60 & 0,89 & disc shaped \\
\hline 21 & 40 & 25 & 21 & limestone & 0,84 & 0,62 & cylindrical \\
\hline 22 & 36 & 25 & 23 & limestone & 0,92 & 0,69 & cylindrical \\
\hline 23 & 35 & 25 & 17 & limestone & 0,68 & 0,71 & spherical \\
\hline 24 & 41 & 23 & 16 & limestone & 0,69 & 0,56 & cylindrical \\
\hline 25 & 30 & 23 & 19 & limestone & 0,82 & 0,76 & spherical \\
\hline 26 & 31 & 27 & 24 & limestone, orange colored & 0,88 & 0,87 & spherical \\
\hline 27 & 34 & 32 & 12 & limestone & 0,37 & 0,94 & cylindrical \\
\hline 28 & 28 & 22 & 14 & limestone & 0,63 & 0,78 & cylindrical \\
\hline 29 & 28 & 24 & 19 & limestone & 0,79 & 0,85 & spherical \\
\hline 30 & 26 & 23 & 22 & limestone & 0,95 & 0,88 & spherical \\
\hline
\end{tabular}

spring) the deposits are transported by water. The drop of temperatures in winter leads to the sheer mechanic disintegration of the rocks, which have become very heated during the summer. Consequently crevices of various sizes are formed. Spring rainfall is the heaviest and the most intensive. The seep- age of water through the crevices plays a key role in the rocks tearing apart and moving down the slope through the power of gravity. The largest pieces are deposited at the greatest distance. The second peak in rainfall is in the autumn, which in turn is the second period of high activity. 

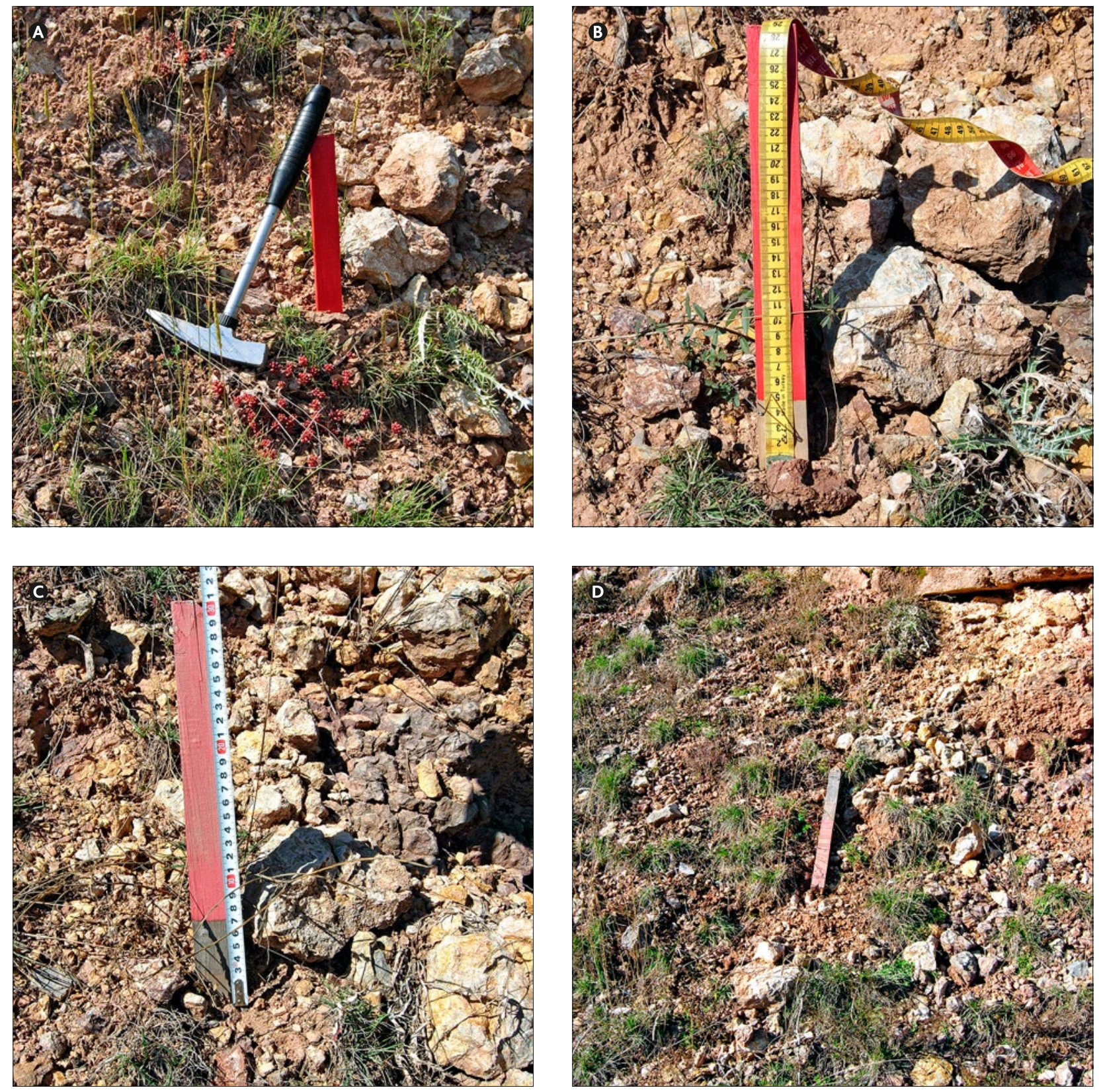

Figure 8. Regular reports on marked stake for 4- years observation period:

A) time sequence - 07.07.2006 B) 29.10.2006 - 4,6 cm denudation C) 16.09.2007 - 6,6 cm denudation D) 29.11.2009 -

$22 \mathrm{~cm}$ denudation - the rod is inverted and moved $1 \mathrm{~m}$ over the slope

\section{The rockfall at the end of observation}

The development of the rockfall in the beginning and in the end of the 4-years' period of observation is presented on Figure 9. To the left is the rockfall as of 07.07.2006 and to the right - as of 05.04.2010. The pictures provide clear evidence that the rockfall process has been very dynamic. The results of the marked stake also confirm this conclusion. The maximum size of the newly fallen rock fragments varies as follows: $19 / 18 / 7,19 / 13 / 8,19 / 12 / 7,15 / 11 / 7,13 / 10 / 6.5,42 / 32 / 13$, $35 / 21 / 20,23 / 19 / 16,36 / 17 / 15,17 / 13 / 7$ (in cm). Driven by the power of their own weight, the largest chunks are transported at the greatest distance, thus reaching the road, while the smaller material is deposited on the slope over the previously fallen rocks. The big number of newly collapsed large blocks near the road indicates that the process entails risks and makes reinforcement measures obligatory.

\section{The rockfall after the earthquake}

The amount of the collapsed mass as a consequence of the earthquake of Mw 5.6 in Pernik (22.05.2012) is calculated using mathematical formulas for the calculation of the area of an ellipse and the volume of a cone. The rockfall is assumed to be an about $4.5 \mathrm{~m}$ high cone whose peak is at the base of the pine tree (on top of 

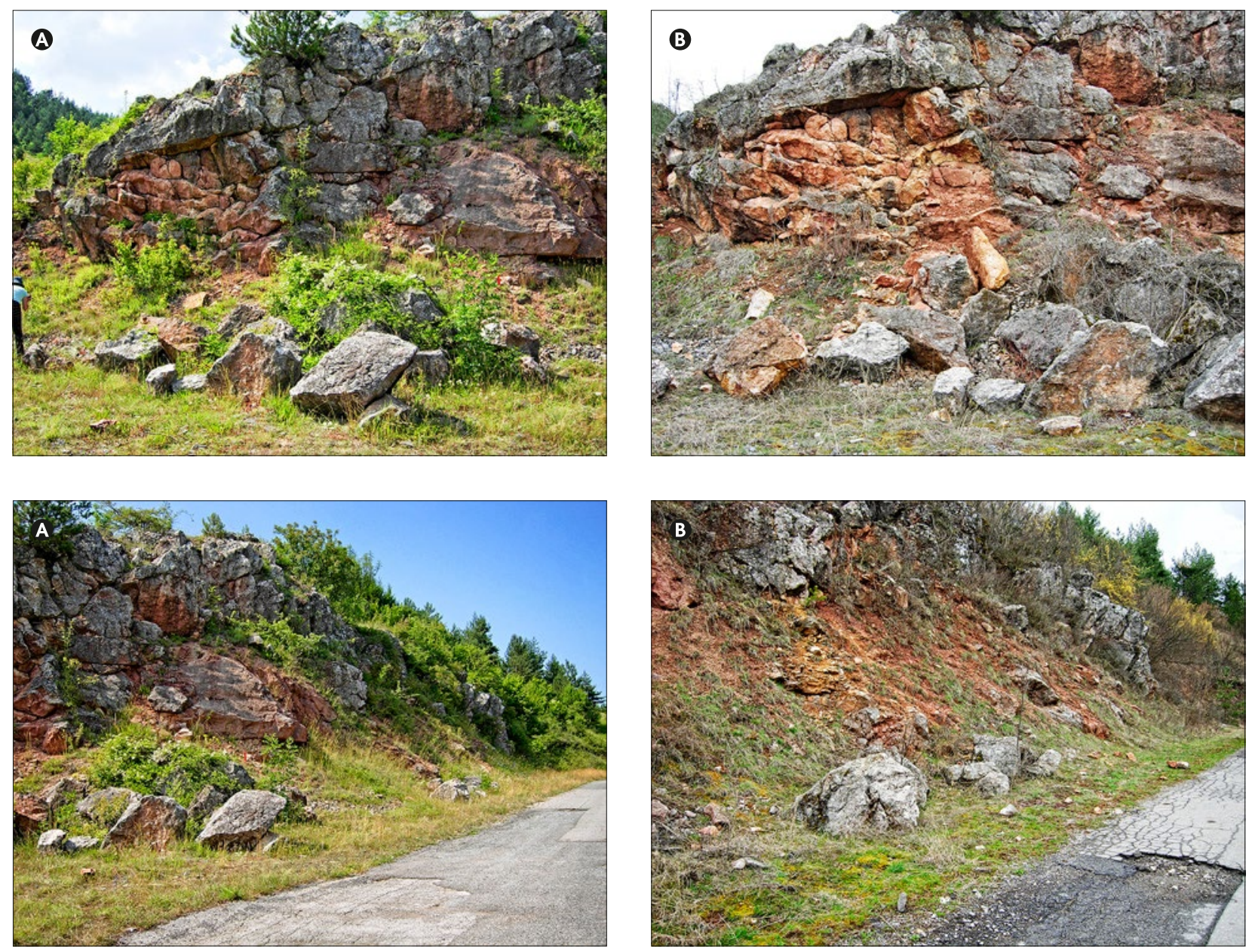

Figure 9. Dynamics of rockfall for 4-years of observations. A - on 07.07.2006 B - on 05.04.2010

the cone). The base of the rockfall is assumed to be an ellipse with a major axis of $7.5 \mathrm{~m}$ and a minor axis of $3.5 \mathrm{~m}$ (Figure 10). The Figure clearly shows that the so formed cone is not completely full of rock mass. There is an empty space of about $35 \%$ which is subtracted from the calculated volume. Thus the calculated volume of collapsed rock mass as a result of the earthquake amounts to approximately $22 \mathrm{~m}^{3}$.

The dynamics of rockfall due to the seismic factor is shown on Figure 11. The dimension of the larg- est fallen blocks on axes $\mathrm{a}, \mathrm{b}$ and $\mathrm{c}$ in $\mathrm{cm}$ are as follows: 101/63/50, 106/85/48, 108/71/53, 105/69/43, 96/48/42, $87 / 56 / 49,73 / 43 / 26,78 / 52 / 28,68 / 45 / 21,84 / 49 / 38$. The number of blocks has grown, too. While the number of larger collapsed blocks (about $100 \mathrm{~cm}$ on axis a) varies between 5 and 8 during the four-year period prior to the earthquake, their number has grown several times after the earthquake. After the falling and the accumulation of rock mass it can be clearly seen that the roots of the plants grow in the crevices and reach further than

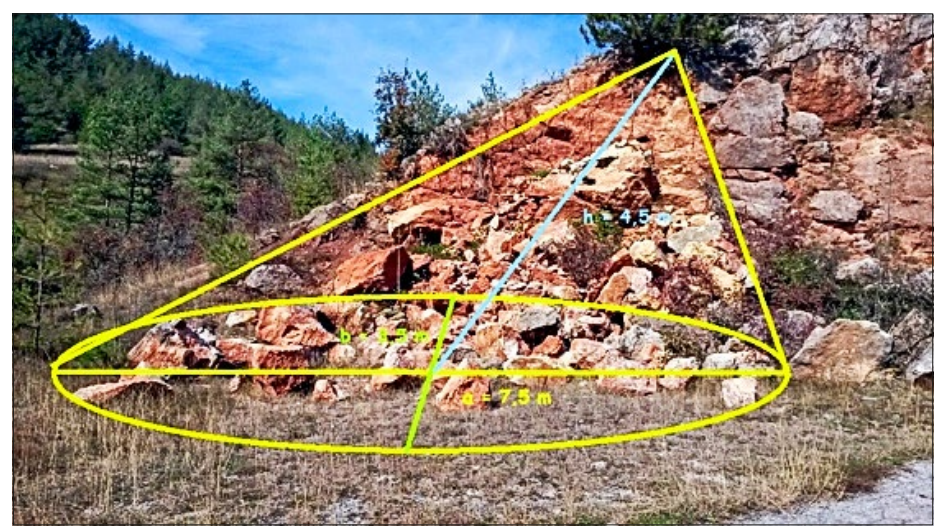

\author{
$\mathrm{S}=\pi \cdot \mathrm{a} \cdot \mathrm{b}$ \\ $\mathrm{S}=3,14 \times 3,75 \times 1,75$ \\ $\mathrm{S}=20,61 \mathrm{~m}$ \\ $a=7,5 \div 2=3,75 \mathrm{~m}$ \\ $b=3,5 \div 2=1,75 \mathrm{~m}$ \\ $h=4,5 \mathrm{~m}$ \\ $\mathrm{V}=1 / 3 \mathrm{~h} . \mathrm{S}$ \\ $V=1 / 3 \quad 4,5 \times 20,61$ \\ $\mathrm{V}=30,91 \mathrm{~m}$ \\ $30,91-35 \%=21.64 \mathrm{~m}^{3}$
}

Figure 10. Calculation the volume of the follen mass 

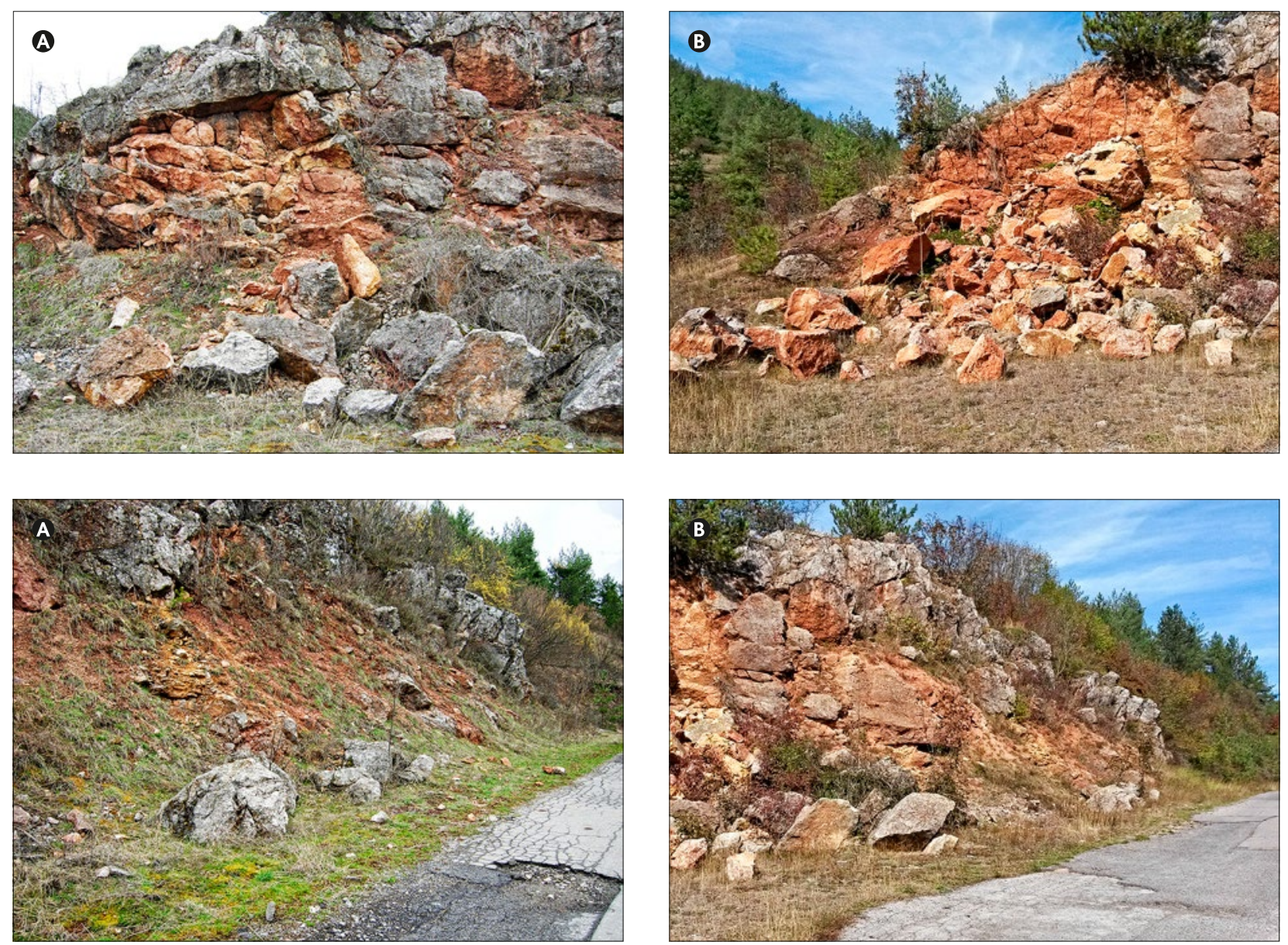

Figure 11. The dynamics of rockfall in a result of seismic activity. A - before the earthquake B - after the earthquake

$1 \mathrm{~m}$ deep, thus destroying the rocks. The cohesion of the minerals deteriorates further and the crevices grow. The limestone is oxidized and subject to physical weathering as well as biological weathering.

\section{Conclusion}

The comparison of the size of the rock blocks before and after the earthquake indicates that their dimensions are quite similar. The same holds true in respect of the way of accumulation. Most of the largest blocks are deposited at the greatest distance from the slope, while the smaller ones are deposited in the vicinity. Therefore, it can be concluded that the size of the collapsed blocks is determined by the crevices caused by weathering in horizontal and subvertical direction which bear no relation to the earthquake. In the crevices the rocks cohesion is damaged and the power of gravity along with the rainfall or the earthquake has brought about the falldown. There is a marked contrast in the volume of collapsed rock mass before and after the earthquake. Before the latter, over a period of 4 years, single large collapsed blocks have been registered, while after the earthquake there are tens of large fallen blocks. The total volume of the fallen rock mass amounts to $22 \mathrm{~m}^{3}$.
The obtained empirical data, as well as its qualitative and quantitative characteristics, provide explicit information about the development of the rockfall before the earthquake. The data is in sharp contrast to the rockfall dynamics after the earthquake with respect to the size of the rock blocks and the volume of collapsed mass. The data allows the authors to examine the development of the rockfall before and after May $22^{\text {nd }} 2012$ and to emphasize the role of the seismic factor for the progress of the gravity processes. The article attempts to quantitatively define the earthquakecaused deformations and characterize the collapsed rock mass. The petrographic analysis and the data from the geological map clearly state that the rockfall is situated on the periphery of a fault located in the valley of the Butroinska River. The fault will be an object of further analysis and examination in the future.

\section{Acknowledgements.}

We would like to express our very great appreciation to Assoc. Prof. Ivan Dimitrov for the petrographic anal$y$ sis of the thin sections and to Assoc. Prof. Boris Valchev for his valuable and constructive suggestions during the development of this article. 


\section{References}

Baltakov, G. 1988. Quaternary geomorphology and Paleogeography. SU “Kl. Ohridski” Publ. House, Sofia, $275 \mathrm{pp}$.

Baltakov, G., Kenderova, R. 2003. Quaternary paleogeography. Maleo - 63, Varna, 324 pp. (in Bulgarian)

Boyadzhiev, S. 1979. Srednogorski neointrusive magmatism in Bulgaria. Geohim. Minerals. and oil. 10, 89-90 (in Bulgarian)

Burrough, P A., McDonell, R. A., 1998. Principles of Geographical Information Systems. Oxford University Press, New York, 190 pp.

Kanev, D. 1989. Geomorphology of Bulgaria. SU "Kl. Ohridski” Publ. House, Sofia, 299 pp. (in Bulgarian)

Klyukin, A. A., Tolstykh E. A. 1984. Methods for measuring the quantitative parameters of the exogenous processes. Nedra, Moscow, 117 pp.

Konstantinov, Hr. 1985 Application of dichotomous system as geomorphological indicator for the development of the hydrographic network of Upper Struma River. Annual SU, GGF, 78, 2 - Geography. 73-81 (in Bulgarian with English summary)

Konstantinov, Hr. 1986. Guide for practical exercises in geomorphology. SU "Kl. Ohridski” Publ. House, Sofia, 237 pp. (in Bulgarian)

Konstantinov, Hr., Kanev, G. 1986. Geomorphological development of the terrain in the upper catchment of the rivers Konska and Yablanitsa. Annual SU, GGF, 79, 2 - Geography. 78-84 (in Bulgarian with English summary)

Kostadinov, V. 1974. Block structure of the northeastern departments of Kraishte in Bulgaria. Reports. geol. institut, BAS, Tectonics 23, 21-29 (in Bulgarian)

Lacroix, P., Helmstetter, A. 2011. Location of Seismic Signals Associated with Microearthquakes and Rockfalls on the Séchilienne Landslide, French Alps. Bulletin of the Seismological Society of America 101, 1, 341-353

Lari, S., Frattini, P., Crosta, G. 2014. A probabilistic approach for landslide hazard analysis. Engineering Geology 182, 3-14
Luuk, K., Dorren, A. 2003. A review of rockfall mechanics and modelling approaches. Progress in Physical Geography 27, 1, 69-87

Marzorati, S., Luzia, L., De Amicis, M. 2002. Rock falls induced by earthquakes: a statistical approach. Soil Dynamics and Earthquake Engineering 22, 565-577

Mavrouli, O., Corominas, J., Wartman, J. 2009. Methodology to evaluate rock slope stability under seismic conditions at Sola de Santa Coloma, Andorra. Natural Hazards and Earth System Sciences 9, 1763-1773

Rizova, R. 2011. Neogenic and contemporary morphogenesis of the Lyulin mountain, the Viskyar mountain and the Zavalska mountain. Dissertation paper, 178 pp. (in Bulgarian)

Rosser, N., Lim, M., Petley, D., Dunning, S., Allison, R. 2007. Patterns of precursory rockfall prior to slope failure. Journal of Geophysical research 112, F4, 1029-1033

Serebryanyi, L. R. 1980. Laboratory analysis in geomorphology and Quaternary paleogeography. Viniti, Moscow, 152 pp. (Results of Science and Technology. Geomorphology, T. 6).

Tricart, J., Cailleux, A. 1963. Initiation a l'étude des sables et des galets. Vol. III, Centre de documentation universitaire, Paris (in French)

Vaptsarov, Iv. 1985. Detailed structural and geomorphological research of the Sofia seismic area in order to develop a model of contemporary crustal movements in geodynamic polygon. Reports of Bulgarian Academy of Sciences 42-51 (in Bulgarian)

Velchev, A. 1998. Landscape structure of the foothills of Lyulin and Viskyar mountains in Bankya - Pozharevo. Probl. of Geography, book 3-4, 134-141 (in Bulgarian with English summary)

Zagorchev, I., Marinova, R., Chunev, D. 1991. Geological map of Bulgaria M 1: 100 ooo map sheets: Breznik (in Bulgarian)

Zimmer, V., Collins, B., Stock, G., Sitar, N. 2012. Rock fall dynamics and deposition: an integrated analysis of the 2009 Ahwiyah Point rock fall,Yosemite National Park, USA Earth Surf. Process. Landforms $37,6,680-691$ 